up to $72 \mathrm{hr}$., and such divisions as are seen are abnormal. Essentially identical mitotic abnormalities are seen in the cells of growing Vicia roots 24,48 and $72 \mathrm{hr}$. after immersion for one hour in aqueous solutions of the compound in concentrations of $10^{-5}$ to $10^{-8}$. At $10^{-8}$ to $10^{-4}$ it completely suppresses mitosis, causes marked pyknosis of the cells, and kills some roots.

Its administration to normal animals of several species results in a fairly uniform pattern of pathological change. The lymphoid tissues are widely attacked and become depleted to a variable extent of lymphoid cells, with replacement by proliferated reticulo-endothelial cells : in some animals areas of total necrosis have been seen in the lymph nodes and spleen. Severe damage is sustained by the bone marrow and is reflected in a fall in the leucocyte count of the blood. In Feulgen-stained smears of the bone marrow, evidence is found of the suppression of mitosis, while those cells in division show many abnormalities, including 'specific chromosome effects'. Testicular damage ranges from mild changes in a few tubules in some animals to complete loss of spermatogenesis with cell desquamation and the appearance in the tubules of multinucleate giant cells in others. Necrotic changes of very variable extent are en. countered in the liver and adrenal, and very occasionally in other organs.

It is clear from our results that active members of the three chemical classes mentioned have many biological properties in common. Moreover, the effects they produce are strikingly reminiscent of those attributed to the 'nitrogen mustards' (vide, for example, Gaensler et al. $\left.{ }^{10}\right)$. We consider that these are manifestations of a common cytotoxic action with specific characteristics. In all cases where it has been studied, their action upon proliferating cells results in the appearance of those abnormalities, chromosome fragmentation and bridge formation, that are distinctive of mitotic poisons of the radiomimetic class (cf. Loveless and Revell, loc. cit.).

The production by these compounds of such specific chromosome abnormalities prompted us to examine their potentialities in two other directions. A selection has now been on test as carcinogenic agents in rats and mice for periods up to one year, and some are being tested on fungal spores for mutagenic activity. The evidence for carcinogenic activity is strongest so far for the compound vinylcyclohexene dioxide (III), which has given rise to one transplantable rat sarcoma and several malignant tumours in mice, while butadiene dioxide (II) has given evidence of mutagenic activity.

Chemically, our active compounds resemble each other and the active 'nitrogen mustards' in that the molecule of each carries at least two alkylating groups capable of interaction with active hydrogen atoms. In consequence they are all potential cross-linking agents ; but while this capacity appears to be necessary for biological activity, it is not a sufficient condition. Although linear bifunctional methylolamides, for example, may function as cross-linking agents, we have shown that they have no action on tumour grawth. From consideration of our results it appears that only those substances are active which are capable of polymerization to yield linear structures with reactive alkylating groups spaced at intervals along the axes. With the aid of models it can be shown that these reactive groups may appear on alternating sides of the polymer chain, and at distances apart which are approximate multiples of
3.7 A. This distance corresponds nearly to the spacing of the purine and pyrimidine residues in the nucleic acids and of the amino-acids in extended polypeptides, and we conceive of such polymers, formed perhaps within the cells, providing a comparatively stable multi-point attachment on protein or nucleic acid chains, for example, those associated with sister chromatids of the dividing cell. This might well give rise to the mitotic abnormalities observed and form the basis of such biological properties as are common to all the compounds in question.

The results and speculations which we have outlined above will be published in greater detail in the near future. Although they are presented here mainly on account of their current theoretical interest, they appear to us to justify the clinical trial in human malignant disease of some of the more active of the compounds described. Such trials have already been initiated with $M .7924$ (I) and $M .9500$ (VI).

${ }^{1}$ Templeman, W. G., and Sexton, W. A., Nature, 156, 630 (1945).

2 Haddow, A., and Sexton, W. A., Nature, 15\%, 500 (1946).

3 Paterson, E., Haddow, A., Ap Thomas, I., and Watkinson, J. M., 4 Skipper, H. E., and Bryan, C. E., J. Nat. Cancer Inst., 9, 391 (1949). S Skipper, H. E., Bryan. C. E., Riser, W. H., jun.,Welty, M., and

- Evans, J. G., "Fibre Science", 248 (Textile Institute, Manchester, 1949).

'Haddow, A., Kon, G. A., and Ross, W. C. J., Nature, 162, 824 (1948). ${ }^{3}$ Goldacre, R. J., Loveless, A., and Ross, W. C. J., Nature, 163, 667 (1949).

- Loveless, A., and Revell, S., Nature, 164, 938 (1949).

${ }^{10}$ Gaensler, E. A., McKay, D. G., Ware, P. F., and I,ynch, J. P., Arch. Path., 46, 503 (1948).

\section{EARLY DAYS OF GENETICS IN BRITAIN}

$G$

ENETICS celebrates its jubilee this year, for it was in 1900 that Mendel's epoch-making paper was rescued from thirty-five years of obscurity and neglect. Thus the whole of the active history of genetics falls within, if only just within, the academic life-span of a man. Into this half-century has been crowded a wealth of discovery, a development of theory, and, we may well add, an interplay of personalities which it would be difficult to match during any corresponding period in any single science. The rise of genetics has been remarkable in its speed and fascinating in its turbulence. It was born in Mendel's frustration, and grew up in the strife between Bateson and Pearson, between the Mendelians and the biometricians. The tradition dies hard; but the later battles, for the chromosome theory, for parasynapsis as opposed to telosynapsis, for the interpretation of the chiasma, for the theory of the geneand now even for genetics itself-are more recent and more familiar to us all.

The great names of the early life of genetics have, of course, all gone-Correns, De Vries, Johannsen, Wilson and the rest. Bateson died in 1926 and Pearson in 1937. Most of the younger British geneticists of the time-Doncaster, Lock and Gregory-preceded them, to the lasting detriment of genetics in Britain. Few even of the senior geneticists of to-day played any active part in those early conflicts which laid the foundation now taken so much for granted, namely, the foundation of virtually universal and virtually exclusively Mendelian (or as we should now say, nuclear) inheritance in the living kingdom. Prof. R. C. Punnett, the chief of Bateson's 
collaborators, is, however, happily still with us to recall for us the story of those times in a way impossible for any but one who was an active participator. This he did in his address, "Early Days of Genetics", delivered to the hundredth meeting of the Genetical Society in Cambridge last year, and now published in Heredity $(4,1-10 ; 1950)$.

Prof. Punnett begins by sketching in the background of morphological Darwinism, as it was towards the end of the past century. From Gelton's attempt to give precision to the notions of variation and heredity grew the biometrical school led by Pearson the mathematician and Weldon the zoologist. Theirs was the orthodoxy with which Bateson clashed : a clash which was coloured by the early association and friendship of Weldon and Bateson at St. John's College, Cambridge. This clash preceded the revela. tion of Mendel's paper in 1900 , a revelation which, of course, confirmed Bateson in his view that variation was discontinuous and which set him off with added vigour on his experimental line of inquiry. We can read of the shifts to which Bateson and his small band were reduced by shortage of funds to support their experiments; of tending the poultry and of growing the sweet peas; of the dark business of 'openings' when unhatched chicks were taken from their eggs for classification; and of the rides to the farm for classifying the sweet peas which it was impossible to grow in Bateson's garden. The difficulties of publication, too, were serious in these early days, and the Reports to the Evolution Committee of the Royal Society (of which Bateson eventually became secretary) afforded the only free channel.

Some of the occasions of which Prof. Punnett writes have a drama seldom found at scientific meetings. The session at the British Association meeting in 1904, when the Mendelians presented their case and fought off the attacks of Weldon and Pearson, deserves almost to rank beside that other and earlier session which Bishop Wilberforce and T. H. Huxley made famous. On another occasion, at the Royal Society, Hurst's Mendelian interpretation of the inheritance of chestnut in horses was successfully challenged by Weldon from his own study of the "Stud Book", and to Bateson's intense annoyance the paper had to be withdrawn. But we can scarcely share this annoyance. We are given the story of "Ben Battle", the horse who was registered as a chestnut and who sired bays from chestnut mares; a story which teaches us not to be conservative or restrictive in our reading. For "Ben Battle", though entered in the "Stud Book" as a chestnut, was revealed by "Form at a Glance" always to have raced as a bay. Mendelism in horses was saved.

The history which Prof. Punnett relates is essentially personal, whether he is describing the conduct of experiments, the clashes with opponents, or his own association with G. H. Hardy both in the secretaryship of the Committee for the Retention of Greek in the Previous Examination and on the cricket field-an association which resulted in the formulation of Hardy's Law, upon which population genetics has been built. It is this personal element, this re-living of those early days, which lends fascination to the story. Prof. Punnett's account will appeal not merely to the geneticist interested in the rise of his science. The colour which he paints into the early geneticel scene must surely command a wider audience-one which will include all biologists, for all are now feeling the repercussions of the events which he so vividly describes.

\section{OBITUARIES}

\author{
Mr. Henry G. Maurice, C.B.
}

Henry Gascoyen MaUrice, fisheries secretary of the Ministry of Agriculture and Fisheries during 1912-38, and former president of the Zoological Society of London, died in London on May 12 at the age of seventy-five. He was educated at Marlborough and Lincoln College, Oxford, graduating in Honour Moderations and Greats ; and afterwards spent some time in coaching and travel before being called to the Bar at Lincoln's Inn in 1904. He then joined the Board of Education and, as private secretary to Sir Walter Runciman, accompanied him to the Ministry of Agriculture and Fisheries, and eventually was appointed to take charge of the Fisheries Department. At first Maurice's appointment aroused some criticism among zoologists, but his wise judgment, tactful handling of his staff, friendly and unassuming manner soon won the affection and confidence of all who came in contact with him. He was largely responsible for the formation of the Fisheries Committee of the Development Com. mission, and the development of fisheries research laboratories in Great Britain. He was also interested in the development of the whaling industry and the preservation of whales, and was an original member of the Discovery Committee of the Colonial Office.

Maurice was president of the International Council for the Exploration of the Sea during 1920-38, and afterwards president d'honneur; for his services he was awarded the Gold Medal of the Johannes Schmidt Foundation for Oceanographical Research. He served for many years on the Counail of the Marine Biological Association and the Challenger Society : his address to the latter in 1945, "Where the Society stands", aptly summarizes the early history of the Challenger Society and its future possibilities.

A much wider public, however, will remember Maurice as a field naturalist. At Marlborough an interest in birds and bird-watching was stimulated by his senior school-fellow, J. Stanley Gardiner, and as a keen angler be acquired a wider acquaintance with Nature. Some years before his retirement he went to live near Regent's Park and became a constant visitor to the Zoological Gardens. He was elected to the Council of the Zoological Society in 1926, and from then onwards took a more active interest in its affairs. In 1942 he succeeded Lord Onslow as president of the Society and held this office until 1948, helping to pilot the Society through the difficult post-war period. His services were recognized by the award of the Society's Gold Medal, conferred only three times previously.

Maurice took a very active part in Nature protection, and as secretary of the Society for the Preservation of the Fauna of the Empire helped to arouse a wider interest in the subject and promote necessary legislation. He was editor of the Fauna Journal and one of its main contributors. As a member of the Commission of the Institut des Parcs Nationaux du Congo Belge, he expounded his views in an address given (in French) at the Fondation Universitaire, Brussels, under the title "Parle a la terre". He led the British delegation to the inaugural conference at Fontainebleau in 1948 which resulted in the foundation of the Intermational Union for the Protection of Nature, and was one of its first vicepresidents. 